\title{
Roles of galectin-3 in the tumor microenvironment and tumor metabolism (Review)
}

\author{
YANAN GUO, RONG SHEN, LINGHUI YU, XIN ZHENG, RONG CUI, YANFENG SONG and DEGUI WANG
}

School of Basic Medical Sciences, Lanzhou University, Lanzhou, Gansu 73000, P.R. China

Received June 20, 2020; Accepted August 24, 2020

DOI: $10.3892 / o r .2020 .7777$

\begin{abstract}
Galectin-3 is expressed in various tissues and plays an important role in the tumor microenvironment (TME). Galectin-3 has been found to be overexpressed in a variety of cancers and is associated with tumor progression and metastasis. Over the past decades, emerging evidence has suggested that the TME may induce galectin-3 expression to maintain cellular homeostasis and promote cell survival. Furthermore, galectin-3 regulates immune cell function to promote tumor-driven immunosuppression through several mechanisms. In the TME, intracellular and extracellular galectin-3 has different functions. In addition, it has been reported that galectin-3 is associated with glycolysis and mitochondrial metabolism in tumors, and it is involved in the regulation of relevant signaling pathways, thus promoting cancer cell survival via adapting to the TME. The aim of the present review was to summarize the current knowledge on galectin-3 production and its function in the TME, its effect on TME immunosuppression, its association with tumor metabolism and relevant signaling pathways, and to report common types of cancer in which galectin-3 is highly expressed, in order to ensure a comprehensive understanding of the critical effects of galectin-3 on tumor progression and metastasis.
\end{abstract}

\section{Contents}

1. Introduction

2. Role of galectin-3 in the TME

3. Association between galectin-3 and tumor metabolism

4. Role of galectin- 3 in tumors

5. Conclusions and future perspectives

Correspondence to: Dr Yanfeng Song or Professor Degui Wang, School of Basic Medical Sciences, Lanzhou University, 99 Donggang West Road, Lanzhou, Gansu 73000, P.R. China

E-mail: songyanfeng@lzu.edu.cn

E-mail: wangdegui@lzu.edu.cn

Key words: galectin-3, tumor microenvironment, glycolysis, mitochondrial, metabolism

\section{Introduction}

Galectin-3 is a $29-35-\mathrm{kDa} \beta$-galactoside-binding glycoprotein (1), which has been widely investigated in several disorders, such as cancer and metabolic diseases (2). Galectin-3 possesses a highly conserved $\beta$-galactoside-binding domain (carbohydrate recognition domain) and an extended $\mathrm{N}$-terminal domain (1-5). The galectin family in mammalians consists of 15 members, including galectin-3 (6). Based on their molecular structure, the 15 members of the galectin family are divided into three main categories: Prototype galectins (galectin-1, -2 , $-5,-7,-10,-11,-13$ and -14 ), tandem repeat galectins (galectin- 4 , $-6,-8,-9$ and -12 ), and chimera galectins (galectin-3) (5). The conformation of galectin-3 alternates into homodimers or oligomers by assembly in its N-terminal domain. Therefore, due to its oligomer form, galectin-3, but not the other galectins, has unique biological properties (6-8).

Galectin-3 is located in the cytoplasm and nucleus, and it is transported to the cell surface, extracellular space and circulation without the secretory signal sequence (9). It has been reported that galectin-3 binds with substrates in cells. For example, intracellular Bcl-2 may be bound by galectin-3 to inhibit T-cell apoptosis (10-12). Furthermore, galectin-3 binds with T-cell receptor (TCR) on the cell surface to restrict and downregulate TCR expression, thus resulting in the inhibition of TCR-mediated early activation of T cells $(13,14)$. When galectin-3 reaches the extracellular space, it reacts with several binding partners, mostly extracellular matrix (ECM) or cell surface polylactosamine-rich molecules, and plays a key role in regulating tumor progression extracellularly $(15,16)$. In the inflammatory response, galectin- 3 has been associated with the activation of neutrophils in several infectious diseases, such as viral lower respiratory tract infection, bacterial sepsis and candidemia (17-20). The R186S mutation in galectin-3 alters its affinity for various carbohydrates, thus playing an important role in its function (21). It was previously demonstrated that the R186S galectin-3 mutant was able to bind lactose, but not LacNac, and was unable to enter vesicles to activate primed neutrophils (22). Galectin-3 has been shown to direct glycoproteins into vesicles, which in turn are transported though the membrane in a lipid raft-independent manner (21). However, it has been suggested that the R186S galectin-3 mutant is not capable of mediating the intracellular transport of glycoproteins, such as gp114 (23). 
The survival and prognosis of cancer patients are not only associated with cancer cells, but also with the tumor microenvironment (TME), which is constituted of cancer cells, immune cells, stromal cells, the ECM, as well as other components. Furthermore, the TME contributes to tumor growth, invasion, metastasis and immunosuppression. For example, it is well known that tumor-associated macrophages, fibroblasts and tumor cells secrete suppressive cytokines and chemokines that are involved in the immune response. Furthermore, the production of inhibitory metabolites, migration failure due to rigid ECM, poor antigen expression and decreased TCR signaling all contribute to tumor progression (24). Tumor-secreted galectin-3 has been found to inhibit the permeation of interferon- $\gamma(\mathrm{IFN}-\gamma)$ in the TME, thus resulting in reduced CXC motif chemokine ligand 9 content and decreased recruitment of $\mathrm{CD}^{+} \mathrm{T}$-cells to the tumor. However, treatment with galectin-3 inhibitors recovered the content of IFN $\gamma$ and chemokines in the TME, whereas the immune cell infiltration was enhanced (25).

Galectin-3 also participates in cell glycolysis and mitochondrial metabolism in some tumors, thus improving the metabolic reprogramming of tumors and enabling them to adapt to the microenvironment stress caused by oxygen and nutrient deprivation $(4,21,26-28)$. Under high-fat diet conditions, galectin-3 knockout (KO) mice exhibited increased levels of fasting blood glucose, insulin and HbAlc. However, the levels of the glucose transporters were lower compared with those in the control group. This finding was hypothesized to be one of the reasons for the increased blood glucose levels observed in KO mice (29). It was previously demonstrated that galectin-3 was co-expressed with glucose transporter 1 (GLUT1) in breast and lung cancer, and their expression was upregulated in tumor cells surrounding the necrotic region inside the tumor (26). Galectin-3 may also be transported to the mitochondrial membrane and interact with Bcl-2, thereby inhibiting the release of mitochondrial cytochrome $c$ and reducing cell apoptosis (30). In addition, inconsistent galectin-3 expression patterns have been identified in different tumors, possibly due to the variation of the TME content or the cellular localization of galectin-3 in different tumor cells (4). For example, previous studies in various cancers have suggested that intracellular galectin-3 plays an important role in maintaining mitochondrial homeostasis, whereas extracellular galectin-3 binds to the CD29 and CD7 glycoproteins on the surface of T-cell lymphoma cells and activates mitochondrial apoptotic signaling (31-33). A mind map of the present study is presented in Fig. 1.

\section{Role of galectin-3 in the TME}

TME induces the production of galectin-3. It has been reported that galectin-3 may be activated in chronic myeloid leukemia (CML), following interaction of leukemic cells in the TME with stromal and mesenchymal stem cells (MSCs) (34-37). A study demonstrated that galectin-3 was upregulated, particularly when leukemic cells were co-cultured with bone marrow stromal cells (BMSCs) in vitro, while its expression was predominant in CML cells (35). Additionally, the expression of galectin-3 was significantly increased when CML cells were co-cultured with MSCs, and the protein expression was the highest during the chronic phase (35). In addition, overexpression of galectin-3 in CML cells promoted CML cell and BMSC proliferation, thereby accelerating the deposition of leukemia cells in the bone marrow. In acute myeloid leukemia, high galectin-3 expression was associated with poor prognosis (38). It has been suggested that galectin-3 supports leukemic cell survival in the TME via the AKT-mediated inactivation of glycogen synthase kinase (GSK)3, which is involved in the anti-apoptotic pathway, pro-cell proliferation cascade, metabolic pathway, and other processes (39-43). In addition, Krause et al demonstrated that galectin-3 was induced when $\mathrm{t}(1 ; 19)$-positive acute lymphoblastic leukemia (ALL) cells were co-cultured with glioma-derived U343 cells. Galectin-3 was considered as ligand of Mer tyrosine kinase and the feedback mechanism between those two elements may mediate the relapse of ALL in the central nervous system (CNS) (44).

The TME, a hypoxic environment, may be regulated by the primary regulator hypoxia inducible factor-1 $\alpha$ (HIF-1 $\alpha$ ), which is known to upregulate the expression of several genes, including galectin-3, to maintain cellular homeostasis and promote cell survival in skeletal tissues (45). Galectin-3 was found to be increased in hypoxic/nutrient-deprived areas from both glioblastoma and mammary tumor tissues (26,46-48). In addition, several studies have demonstrated that the interference of nuclear factor (NF)- $\mathrm{kB}$ activation inhibits galectin-3 expression, resulting in cell apoptosis (49). Taken together, the interactions among galectin-3, NF- $\kappa \mathrm{B}, \mathrm{HIF}-1 \alpha$ and common stress conditions in the TME are crucial for tumor progression (Fig. 2).

Galectin-3 regulates TME immunosuppression. Galectin-3 plays a key role in promoting tumor-driven immunosuppression. The specific effects of galectin-3 on the innate and adaptive immunity are summarized in Table I (15). A study revealed that co-culture of $\mathrm{T}$ cells from the peripheral blood with autologous tumor cells suppressed galectin-3 expression in tumor cells and mediated galectin-3-induced expansion of tumor-reactive $T$ cells (6). In addition, tumor cell-secreted galectin-3 may regulate the polarization of macrophages from the M1 (antitumor) to the M2 (tumor-promoting) subtype, trigger $\mathrm{CD} 8^{+} \mathrm{T}$-cell apoptosis, and downregulate the expression of TCRs (50). Emerging evidence has suggested that galectin-3 binds to lymphocyte-activation gene-3 (LAG-3) on activated terminally differentiated $\mathrm{T}$ cells, and functional LAG-3 is required for galectin-3-mediated T-cell suppression (51). In addition, depletion of galectin-3 was associated with increased activation of the proinflammatory signaling pathways in $\mathrm{CD}^{+} \mathrm{T}$ cells (51). Galectin-3 suppressed T-cell function via inducing T-cell anergy, and this effect was rescued by depleting surface galectin-3 $(52,53)$. The mechanism underlying galectin-3-induced immunosuppression is mainly mediated by triggering apoptosis via its binding to antitumor $\mathrm{T}$ cells $(54,55)$, and shielding the ligands on the surface of tumor cells from the activated receptors of natural killer (NK) cells $(56,57)$. Furthermore, galectin-3 is a soluble ligand of NKp30, which is expressed on the surface of NK cells and acts as an immunomodulator to mediate immune escape of tumor cells from NK cells (58). 
Table I. Typical functions of galectin-3 in innate and adaptive immunity (15).

Innate immunity

Promotes acute inflammation

Potentiates eosinophil migration

Promotes neutrophil transmigration and degranulation

Inhibits IL-12 production from DCs

Mediates alternative activation of macrophages
Adaptive immunity

Induces apoptosis of T cells (extracellular)

Protects T cells from apoptosis (intracellular)

Favors Th2 responses (extracellular)

Favors Th1 responses (intracellular)

Favors differentiation toward memory B cells

DCs, dendritic cells; Th1, T helper cell 1; Th2, T helper cell 2; IL, interleukin.

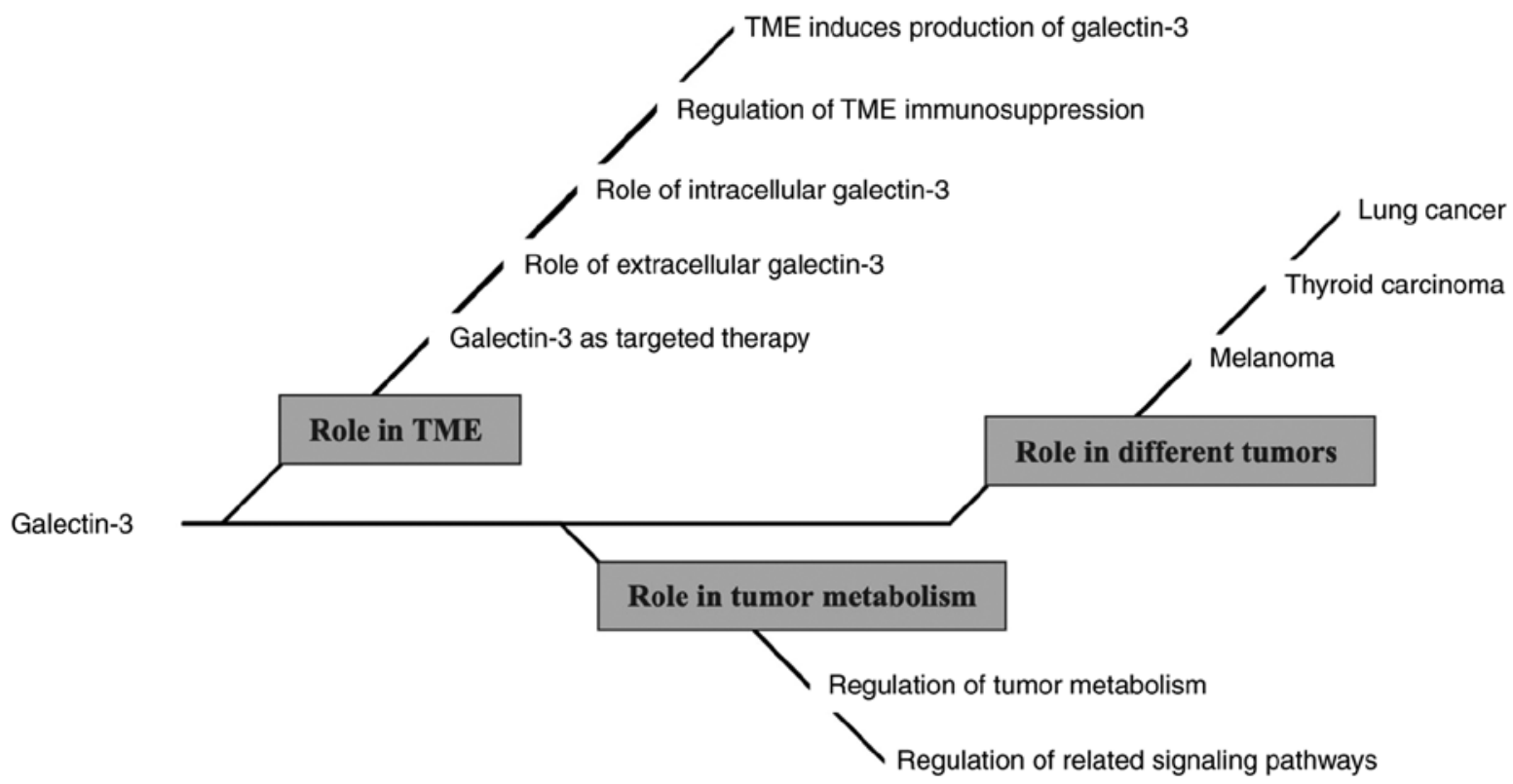

Figure 1. Mind map of article. Galectin-3 mainly plays a role in the TME and tumor metabolism, and exerts specific effects on lung cancer, thyroid carcinoma and melanoma. TME, tumor microenvironment.

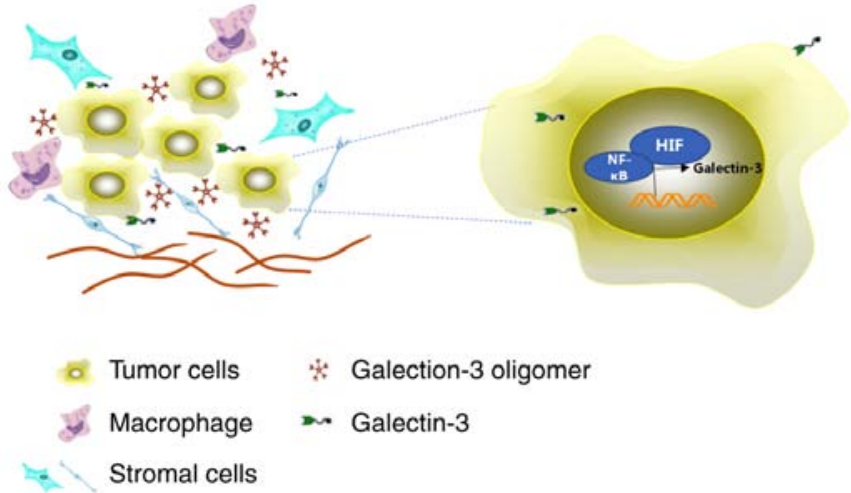

Figure 2. Role of galectin-3 in tumor progression. Galectin-3 transcription depends on the activities of both HIF- $1 \alpha$ and NF- $\kappa$ B in the TME, particularly under hypoxic conditions. NF- $\kappa \mathrm{B}$, nuclear factor- $\kappa \mathrm{B}$; HIF-1 $\alpha$, hypoxia-inducible factor-1 $\alpha$; TME, tumor microenvironment.

Galectin-3 regulates T-cell function through several mechanisms, including the negative regulation of the TCR-mediated cell response (13). Demotte et al demonstrated that treating $\mathrm{CD}^{+}$tumor-infiltrating $\mathrm{T}$ lymphocytes (TILs) with an anti-galectin-3 antibody could restore their ability of IFN- $\gamma$ secretion (52). Furthermore, the proliferation of tumor-reactive $\mathrm{T}$ cells was improved following treatment with supernatants isolated from galectin-3-depleted cells, indicating an important role of the tumor-secreted galectin-3 in the suppression of T-cell activation (59). CD146/MCAM has been reported to act as a functional binding ligand of galectin-3 on the surface of endothelial cells, and is responsible for galectin-3-induced secretion of metastasis-promoting cytokines (60). Certain cytokines, such as interleukin (IL)-1, IL-6, tumor necrosis factor- $\alpha$ and INF- $\gamma$, are associated with metastasis and prognosis in several types of cancer (61). The interaction of galectin-3 with endothelial CD146/MCAM in the circulation resulted in increased secretion of IL-6, granulocyte colony-stimulating factor and other cytokines; therefore, they may exert an important effect on the progression and metastasis of cancer (60).

Extracellular and intracellular galectin-3 exert different effects on lymphocytes; therefore, understanding the function of galectin-3 is complicated (6). Interestingly, the cellular localization of galectin-3 determines whether it exerts apoptotic or anti-apoptotic effects on T cells. It has been reported that extracellular galectin-3 induces apoptosis, whereas intracellular 
galectin-3 inhibits apoptosis by promoting cell proliferation and stimulating TCR signaling (5). Therefore, extracellular galectin-3 may induce apoptosis of human thymocytes and T cells via directly binding to the glycoprotein receptors CD45 and CD71 (62). On the contrary, overexpression of galectin-3 in the intracellular compartment of Jurkat T cells was associated with the inhibition of apoptosis induced by an anti-Fas antibody and staurosporine (63). In addition, a study revealed that depletion of galectin-3 in $\mathrm{CD}^{+} \mathrm{T}$ cells upregulated TCR expression and IFN- $\gamma$ secretion compared with wild-type CD4 ${ }^{+} \mathrm{T}$ cells (13).

Function of intracellular galectin-3 in the TME. An increasing number of studies have investigated the expression levels of galectin-3 in different types of cancer, and its expression was found to differ among diverse malignancies (64). Galectin-3 was shown to be upregulated in thyroid, liver, stomach and CNS cancers, and downregulated in breast, ovarian, uterine and prostate cancers (65-67). During tumor progression, galectin-3 is often localized in the cytoplasm, as has been reported for tongue and prostate cancer (64), and its expression was decreased in the nucleus during the transition of tongue tissue from normal to cancerous (64). It was, therefore, hypothesized that the nuclear translocation of galectin-3 observed during tumor progression may be a prognostic factor for patients with tongue cancer (68). A similar research, including 145 prostate cancer patients, reported that galectin-3 was usually not expressed or decreased in prostate cancer compared with normal prostate tissues (64). When galectin-3 was detected in cancer cells, it was always absent from the nucleus and was only present in the cytoplasm (69). In addition, it has been reported that the expression of galectin-3 in the cytoplasm is closely associated with vascular invasion, cell differentiation and tumor progression (70).

Galectin-3 exerts opposite biological effects, depending on its cellular localization; therefore, nuclear and cytoplasmic galectin-3 exert antitumor and tumorigenic effects, respectively $(69,71,72)$. It has been suggested that galectin-3 is involved in several different signal transduction cascades and pro-survival processes, including the Ras, Bcl-2 and Myc signaling pathways (73-75). For example, galectin-3 regulated Bcl-2 and other members of the Bcl-2 family by directly binding to them (76). The expression of galectin-3 between the cytoplasmic and nucleal regions differs in different types of skin cancer. For example, the cytoplasmic galectin-3 expression in cutaneous squamous cell carcinoma was significantly higher compared with that in circumscribed and infiltrative basal cell carcinoma. Furthermore, the immunoreactivity of galectin-3 in the cytoplasm was increased compared with that in the nuclei of non-melanoma skin cancer cells (77). In addition, it has been hypothesized that tumor size is associated with the cytoplasmic expression of galectin-3. The nuclear and cytoplasmic expression of galectin-3 has been considered as an important factor in the malignant progression of non-melanoma skin cancer. Therefore, the expression of galectin-3 was reported to be decreased in the nucleus and increased in the cytoplasm during the transition of normal cells to tumor cells (50). Consistently, melanoma patients with low survival rate exhibited increased cytoplasmic galectin-3 expression compared with its nuclear expression (78).
Function of extracellular galectin-3 in the TME. Notably, several studies have shown that the behavior of tumor-stromal cells, including endothelial cells, immune cells, cancer-associated fibroblasts, myofibroblasts and MSCs, is affected by the extracellular expression of galectin-3, whereas it has been found that these cells may also secrete galectin-3 (5,79-82). Upregulation of the galectin-3 expression increases the ability of cancer cell migration and invasion in several tumors, including breast, melanoma, lung, sarcoma, gastric cancer and CML (12,35,82-85). In addition, galectin-3 interacts with ECM glycoproteins, such as fibronectin, collagen IV, elastin and laminin, which play pivotal roles in cell migration (86-89). Studies have shown that galectin-3 also interacts with epidermal growth factor receptor (EGFR) to induce its phosphorylation and re-localization from the membrane to the cytoplasm. In the case of colon cancer cell migration, extracellular galectin-3 may bind with EGFR to affect EGFR dynamics (90). Researchers demonstrated that galectin-3 exhibited an increased affinity to $\beta-1,6-\mathrm{N}$-acetylglucosamine branched glycans. This interaction mediated the binding of galectin-3 to several types of glycoproteins and glycolipids on the cell membrane, including carcinoembryonic antigen, mucin-1 and glycosylated transmembrane tyrosine kinase receptors of EGF $(91,92)$. The aforementioned findings suggest that galectin-3 may play multiple roles in regulating cell-matrix and cell-cell interactions in cancer.

In addition, it has been reported that tumor-secreted galectin-3 is involved in angiogenesis via binding through carbohydrate recognition, thus affecting endothelial cell behavior and regulating capillary formation during tumor progression (79). The mechanism underlying galectin-3-mediated angiogenesis has been associated with the binding of galectin- 3 with $\alpha v \beta 3$ integrins on endothelial cells to induce aggregation of integrin clusters and the activation of several signaling pathways. As a result, galectin-3 may affect the angiogenic activity of vascular endothelial growth factor and basic fibroblast growth factor, as well as the promotion of focal adhesion kinase phosphorylation (93).

Galectin-3 as a targeted therapy. Due to the immunosuppressive effects of galectin-3, its role in promoting tumor invasion, migration and angiogenesis in the TME has been attracting increasing attention. Therefore, galectin-3 is considered as a potential target for the clinical therapy of cancer. Although the pre-clinical study of a clinical grade galectin antagonist (GM-CT-01) is still at an early stage, a report demonstrated that this antagonist restored $\mathrm{CD} 8^{+}$ T-cell function, suggesting that this compound may be an effective approach to cancer therapy (94). Furthermore, the effects of galectin-3 antagonists, combined with immune checkpoint inhibitors or T-cell agonists, were investigated to reveal their potential role on enhancing antitumor immunity and promoting regression of solid tumors (95). Preclinical studies demonstrated that treatment with a galectin-3 inhibitor, namely GR-MD-02, a carbohydrate-based drug that binds to galectin-3, promoted antigen-specific T-cell proliferation in patients with advanced cancer $(95,96)$. In addition, GR-MD-02 combined with an irritant (anti-OX40) improved the survival rate of MCA-205 sarcoma, 4T1 breast cancer and transgenic adenocarcinoma of mouse prostate 


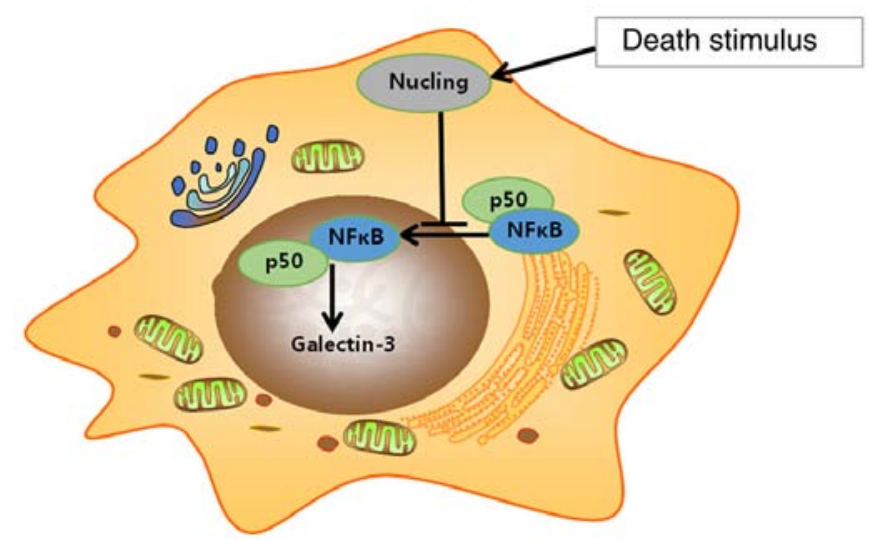

Figure 3. Nucling regulates the expression of galectin-3. Nucling interferes with $\mathrm{NF}-\kappa \mathrm{B}$ activity through preventing the nuclear translocation of the NF- $\kappa$ B-p65 complex from the cytoplasm, thereby inhibiting the expression of galectin-3. NF- $\mathrm{B}$, nuclear factor- $\kappa \mathrm{B}$.

cell (TRAMP-C1) models $(95,97)$. In addition, GR-MD-02 attenuated liver pathological changes, collagen deposition and fibrosis in mice with non-alcoholic steatohepatitis (96). The combination of GR-MD-02 with anti-OX40 treatment also reduced lung metastasis in a 4T1 breast cancer model (98). The successful application of lectin inhibitors indicates that these inhibitors may represent a potential promising approach to cancer therapy.

\section{Association between galectin-3 and tumor metabolism}

Role of galectin-3 in tumor metabolism. Differentiated or undifferentiated normal cells rely heavily on the glycolytic pathway to generate energy. Glycolysis refers to the anaerobic conversion of glucose to pyruvate through a series of intercellular enzymatic reactions to produce adenosine triphosphate (ATP), a high-energy phosphate compound (99). The Warburg effect describes a type of mitochondrial dysfunction, where cancer cells do not allow pyruvate to enter mitochondria; instead, lactate dehydrogenase (LDH) enters mitochondria to degrade pyruvate to lactic acid, which in turn enters the Cori cycle $(99,100)$. In tumor cells, galectin-3 overexpression was associated with HIF-1 $\alpha$ and p53 activity $(21,101)$, and enhanced phosphoinositide 3-kinase (PI3K) signaling to promote GLUT1-mediated aerobic glycolysis in tumor cells $(28,32,102)$. In addition, galectin-3 promoted RAS and extracellular signal-regulated kinase (ERK) 1/2 activation to induce GLUT1 expression and the activity of hexokinase, phosphofructokinase and LDHA (103-106).

It has been reported that galectin-3 is involved in maintaining mitochondrial homeostasis (107). Therefore, in ovarian cancer, cisplatin promoted the release of cytochrome $c$ and mitochondrial reactive oxygen species in cells with galectin-3-silencing. However, the effect of cisplatin was attenuated following galectin-3 overexpression (108). Inhibition of galectin-3 expression in colorectal cancer cells reduced epirubicin-induced ATP-binding cassette transporter expression and activated the mitochondrial apoptotic pathway (33). Galectin-3 has also been suggested to be associated with pivotal regulators of mitochondrial metabolism, such as AMP-activated protein kinase and peroxisome proliferator-activated receptor, two indicators of fatty acid oxidation in mitochondria that regulate metabolic balance in tumor cells $(109,110)$.

Galectin-3 was found to be significantly upregulated in human glioblastoma T98G cells under conditions of hypoxia and nutrient deprivation (48). Consistently, overexpression of galectin-3 enhanced T98G cell survival and adaptation viability. These findings suggested that galectin-3 mediated tumor progression via promoting angiogenesis and maintaining homeostasis in the TME $(48,111)$. In addition, previous studies in melanoma cells have demonstrated that extracellular galectin-3 activates the p38 mitogen-activated protein kinase pathway, thereby inducing the expression of matrix metalloproteinase (MMP)9, which in turn provides nutritional support for tumor angiogenesis $(32,112)$. Therefore, galectin-3 overexpression may be considered as an adaptive metabolic mechanism of the tumor to maintain cellular viability and homeostasis under conditions of TME stress induced by hypoxia and nutrient deficiency.

Galectin-3 is involved in multiple signaling pathways regulating tumor metabolism. It has been reported that the AKT-mediated PI3K signaling pathway is involved in the regulation of GLUT1, glucose uptake and phosphofructokinase activity, thus affecting cell survival, cell cycle progression and therapeutic outcome (99,113-117). Furthermore, galectin-3 has a high affinity for and is cross-linked with $\beta 1,6-G l c N A c-b r a n c h e d ~ N-g l y c a n s$ and glycoproteins to form molecular complexes on the cell surface and ECM, thus affecting the distribution of glycoproteins and cell signal transduction (66). Kariya et al demonstrated that the reactivation of PI3K mediated by $\beta 4$-integrin $\mathrm{N}$-glycans was inhibited following treatment with a neutralizing antibody against galectin-3 (118). Elad-Sfadia et al revealed that galectin-3 was required for the RAS-induced PI3K/AKT activation in response to growth factor stimulation (11). Additionally, galectin-3 increased $\beta$-catenin expression and accumulation in the nucleus, thereby enhancing Wnt signaling in human colon cancer cells via regulating GSK-3 $\beta$ phosphorylation/activity through the PI3K/AKT signaling pathway (39).

$\mathrm{NF}-\kappa \mathrm{B}$ serves an important role in inducing proinflammatory cytokines in several types of cancer $(119,120)$. Emerging evidence has suggested that HIF-1 $\alpha$, NF- $\kappa \mathrm{B}$, caveolin-1 and TP53-inducible glycolysis and apoptosis regulator acted as inducers of cancer-stroma metabolic coupling via modulating oxidative stress and autophagy (121). Upregulation of galectin-3 in a hypoxic microenvironment relies on transcription factors such as HIF- $1 \alpha$ and NF- $\kappa \mathrm{B}(48,122)$. Nucling, an apoptosis-associated molecule, downregulated galectin-3 mRNA and protein expression via mediating the nuclear translocation of NF- $\kappa \mathrm{B} / \mathrm{p} 65$ (Fig. 3). Therefore, nucling-deficient cells were resistant to pro-apoptotic stress, whereas the expression of galectin-3 and the incidence of inflammatory injury were increased in mice lacking nucling (49). Galectin-3 also promoted IL-8 transcription and secretion via $\mathrm{NF}-\kappa \mathrm{B}$ signaling in pancreatic stellate cells; however, treatment with a $\mathrm{NF}-\kappa \mathrm{B}$ inhibitor and integrin-linked kinase (cdp33) completely inhibited the galectin-3-mediated transcriptional activities of NF- $\kappa$ B and IL-8 (123).

Several signaling pathways have been found to be involved in the metabolic process in tumors. Overexpression 
of galectin-3 in the hypoxic TME was considered to regulate tumor cell migration, invasion and adaptability (32). In addition, the $\mathrm{Wnt} / \beta$-catenin pathway was found to be involved in the regulation of cell migration via MMPs (124). Shimura et al demonstrated that galectin-3 interacted with the $\beta$-catenin/TCF complex and was co-localized with $\beta$-catenin in the nucleus, thereby regulating the transcriptional activity of transcription factor 4 (TCF4) in breast cancer cells (125). Consistently, Song et al reported that galectin-3 mediated $\beta$-catenin expression and TCF4 activity by regulating GSK-3 $\beta$ phosphorylation and activation via the PI3K/AKT pathway in colon cancer cells (39). Additionally, downregulation of galectin-3 resulted in reduced phosphorylated (p)-AKT and p-GSK-3 $\beta$ expression, and increased GSK-3 $\beta$ activity, thus mediating the phosphorylation of $\beta$-catenin. This effect was considered as a critical step for the recognition of $\beta$-catenin by the F-box protein $\beta$-Trcp (126). These findings indicated that galectin-3 participates in multiple signaling pathways to regulate tumor metabolism.

\section{Role of galectin-3 in tumors}

Lung cancer. Lung cancer is one of the most common types of cancer worldwide, and non-small cell lung cancer (NSCLC) accounts for $\sim 80 \%$ of lung cancer cases (127). The expression of galectin-3 varies among different types of lung cancer. For example, in small-cell lung cancer, galectin-3 is not expressed or downregulated compared with NSCLC, in which galectin-3 is upregulated in the majority of cases (128). mRNA microarrays revealed that forkhead box D1 (FOXD1) was associated with poor prognosis and lung cancer cell proliferation (129). FOXD1 has been shown to promote lung cancer cell invasiveness via its binding with ERK1/2 and targeting galectin-3 (95). In addition, it has been demonstrated that galectin-3 regulates the expression of FOXD1 via the integrin- $\beta 1 /$ ERK/E26 transformation specific-1 cascade, which in turn mediates the formation of a positive ring between FOXD1 and galectin-3 and promotes lung cancer invasiveness (130). A study suggested that the expression of galectin-3 may be a potential biomarker for predicting NSCLC recurrence after radical resection (131). However, the level of galectin-3 in the serum had no prognostic value in NSCLC, and no significant correlation was observed between NSCLC and galectin-3 serum levels (131). Knockdown of galectin-3 in NSCLC cell line-derived spheres decreased the expression of stemness-associated genes, suggesting that galectin-3 may play a synergistic role by interacting with $\beta$-catenin and increasing the transcriptional activity of downstream stemness-associated genes. Furthermore, cells lacking galectin-3 were less invasive, more vulnerable to chemotherapy, and inefficient in initiating tumor formation (132).

In NSCLC, galectin-3 not only mediates the malignancy of cancer cells, but also attenuates the effect of immune cells on inducing tumor cell evasion from the immune response. It has been demonstrated that the intracellular expression of galectin-3 and galectin-1 in tumor cells may block apoptosis; however, the extracellular galectins within the TME induce T-cell apoptosis via binding with CD45 and CD7 on the surface of $\mathrm{T}$ cells, and exacerbating the immune escape of tumor cells (133). In particular, the galectin-3 multivalent $\mathrm{N}$-glycan complex impaired TCR clustering on the T-cell surface and increased the agonist threshold for TCR signaling (133). In fact, molecular interactions between T-cell surface glycans and certain galectins are functionally capable of regulating T-lymphocyte death and inflammatory responses (25,133-136). Antigen-presenting cells (APCs) and macrophages also play an important role in establishing immune cell homeostasis (137). Significant changes in the glycan chain have been identified during dendritic cell maturation in order to regulate the binding of specific galectins to mature or immature APCs (138).

Thyroid carcinoma. A recent meta-analysis has suggested that galectin-3 may be considered as a potentially useful immune marker for distinguishing patients with papillary thyroid cancer (PTC) from those with non-PTC (139). PTC patients with positive galectin-3 expression are prone to lymph node metastasis (139). A study compared the serum galectin-3 levels between patients with thyroid cancer and healthy individuals. The results revealed that the serum galectin-3 levels in patients with thyroid cancer were significantly higher compared with those in patients with benign thyroid lesions or healthy controls $(140,141)$. PTC and papillary thyroid micro-carcinoma (PTMC) are the most common types of thyroid malignancies $(142,143)$. However, distinguishing PTC and PTMC from thyroid papillary hyperplasia is challenging due to tumor heterogeneity $(144,145)$. Furthermore, the expression profiles of galectin-3, cytokeratin 19, CD56, thyroid peroxidase and BRAF mutations are commonly used for the diagnosis of PTC and PTMC (145-148).

It has been suggested that the galectin family plays an important role in Ras membrane anchoring and Ras-mediated cell transformation $(11,149)$. Ras proteins (H-Ras, K-Ras and $\mathrm{N}$-Ras) are important members of the GTPase family, which regulate cell differentiation, proliferation and cell death (150). Ras mutations are known to be involved in $25-30 \%$ of all human cancers $(151,152)$. In addition, galectin- 3 interacts with oncogenic Ras proteins, preferentially with K-Ras, to promote the activation of important signaling cascades, including serine/threonine kinase (RAF1), PI3K and Ras signaling pathways, and to regulate gene expression at the transcriptional level (11). A study demonstrated that the combination of galectin-3 inhibitor, S-trans,trans-farnesylthiosalicylic acid and modified citrus pectin was able to induce cell cycle arrest and apoptosis, thereby inhibiting the growth of anaplastic thyroid carcinoma in vitro and in vivo (153-155).

Melanoma. Melanoma is the most aggressive skin cancer and is considered as a highly immunogenic tumor (156). Over the past few years, studies have identified the characteristics of progressive biomarkers and their underlying mechanisms based on deep research on the invasion and chemoresistance abilities of melanoma cells, and the association between galectin-3 expression and melanoma pathogenesis (59). The results demonstrated that, compared with benign nevus, the galectin-3 expression levels were increased in thin primary melanomas. However, this expression pattern was lost during tumor progression, and galectin-3 expression was decreased in both thick and metastatic melanomas $(70,157)$. Other studies indicated that the expression of galectin-3 in melanocytes 
and melanoma cells treated with a mutated BRAF inhibitor, vemurafenib, exerted a pivotal effect on reducing autophagic activity and determining cell fate $(158,159)$.

It was previously demonstrated that the expression levels of galectin-3 and its nuclear:cytoplasmic ratio was higher in metastatic lesions compared with that in primary melanoma lesions. Additionally, an association between the nuclear expression of galectin-3 and prognosis was proposed (78). Mourad-Zeidan et al demonstrated that melanoma cells lacking galectin-3 expression exhibited reduced tumorigenic potential and decreased expression of tumor markers (160). However, other studies reported the opposite result. Therefore, a study using a xenograft melanoma model constructed with human melanoma cell lines demonstrated that the expression of galectin-3 was upregulated in thin primary melanoma lesions compared with benign pigmented skin lesions or metastases, and was negatively correlated with cell invasiveness (2). It was also suggested that, in more advanced melanoma lesions, attenuated galectin-3 expression may be associated with high risk of tumor metastasis. Related results indicate that melanoma cells may separate from the basement membrane and enter the circulation via attenuating their interaction with the ECM (2).

\section{Conclusions and future perspectives}

The unique molecular structure of galectin-3 determines its importance in the TME and tumor metabolism. In the TME, tumor cells are more prone to inducing the production of galectin-3 in order to promote their proliferation and survival. In addition, galectin-3 interacts with immune cells and inhibits the normal functions of lymphocytes, thereby mediating the immune escape of tumor cells. In the TME, intracellular and extracellular galectin-3 serve different functions. Of note, galectin-3 is also involved in metabolic pathways in tumors, not only affecting mitochondrial homeostasis, but also contributing to tumor cell adaptation to a hypoxic metabolic environment and metastasis. The characteristic functions of galectin-3 in the TME provide a novel direction for cancer immunotherapy in the clinical setting; however, further studies are required to elucidate the more comprehensive mechanisms underlying the multifaceted biological functions of galectin-3.

\section{Acknowledgements}

Not applicable.

\section{Funding}

The present study was supported by the National Natural Science Foundation of China (grant no. 81772907), the Fundamental Research Funds for the Central Universities (grant no. lzujbky-2020-sp16) and the Gansu Youth Science Foundation Project (grant no. 17JR2JA227).

\section{Availability of materials and data}

Not applicable.

\section{Authors' contributions}

YG was a major contributor to the writing of the manuscript and was mainly responsible for reviewing the role of galectin-3 in the TME. RS was mainly responsible for reviewing the role of galectin-3 in tumor metabolism. YS and DW critically revised the manuscript for important intellectual content. LY, $\mathrm{XZ}$ and $\mathrm{RC}$ were mainly responsible for reviewing the role of galectin-3 in different tumors. All the authors have read and approved the final version of the manuscript.

\section{Ethics approval and consent to participate}

Not applicable.

\section{Patient consent for publication}

Not applicable.

\section{Competing interests}

The authors declare that they have no competing interests.

\section{References}

1. Xue H, Liu L, Zhao Z, Zhang Z, Guan Y, Cheng H, Zhou Y and Tai G: The N-terminal tail coordinates with carbohydrate recognition domain to mediate galectin-3 induced apoptosis in $\mathrm{T}$ cells Oncotarget 8: 49824-49838, 2017.

2. Vereecken P, Debray C, Petein M, Awada A, Lalmand MC Laporte M, Van Den Heule B, Verhest A and Pochet R: Expression of galectin-3 in primary and metastatic melanoma: Immunohistochemical studies on human lesions and nude mice xenograft tumors. Arch Dermatol Res 296: 353-358, 2005.

3. Newlaczyl AU and Yu LG: Galectin-3-a jack-of-all-trades in cancer. Cancer Lett 313: 123-128, 2011.

4. Li YS, Li XT, Yu LG, Wang L, Shi ZY and Guo XL: Roles of galectin-3 in metabolic disorders and tumor cell metabolism. Int J Biol Macromol 142: 463-473, 2020.

5. Fortuna-Costa A, Gomes AM, Kozlowski EO, Stelling MP and Pavão MS: Extracellular galectin-3 in tumor progression and metastasis. Front Oncol 4: 138, 2014.

6. Farhad M, Rolig AS and Redmond WL: The role of Galectin-3 in modulating tumor growth and immunosuppression within the tumor microenvironment. Oncoimmunology 7: e1434467, 2018.

7. Ahmed H and AlSadek DM: Galectin-3 as a potential target to prevent cancer metastasis. Clin Med Insights Oncol 9: 113-121, 2015.

8. Ahmad N, Gabius HJ, André S, Kaltner H, Sabesan S, Roy R, Liu B, Macaluso F and Brewer CF: Galectin-3 precipitates as a pentamer with synthetic multivalent carbohydrates and forms heterogeneous cross-linked complexes. J Biol Chem 279: 10841-10847, 2004.

9. Nangia-Makker P, Hogan V and Raz A: Galectin-3 and cancer stemness. Glycobiology 28: 172-181, 2018.

10. Mehul B and Hughes RC: Plasma membrane targetting, vesicular budding and release of galectin 3 from the cytoplasm of mammalian cells during secretion. J Cell Sci 110: 1169-1178, 1997.

11. Elad-Sfadia G, Haklai R, Balan E and Kloog Y: Galectin-3 augments K-Ras activation and triggers a Ras signal that attenuates ERK but not phosphoinositide 3-kinase activity. J Biol Chem 279: 34922-34930, 2004.

12. Honjo $Y$, Nangia-Makker $P$, Inohara $H$ and $R a z A$ : Down-regulation of galectin-3 suppresses tumorigenicity of human breast carcinoma cells. Clin Cancer Res 7: 661-668, 2001.

13. Chen HY, Fermin A, Vardhana S, Weng IC, Lo KF, Chang EY, Maverakis E, Yang RY, Hsu DK, Dustin ML and Liu FT: Galectin-3 negatively regulates TCR-mediated CD4 ${ }^{+}$T-cell activation at the immunological synapse. Proc Natl Acad Sci USA 106: 14496-14501, 2009. 
14. Grigorian A and Demetriou M: Manipulating cell surface glycoproteins by targeting n-glycan-galectin interactions. Methods Enzymol 480: 245-266, 2010.

15. Di Lella S, Sundblad V, Cerliani JP, Guardia CM, Estrin DA, Vasta GR and Rabinovich GA: When galectins recognize glycans: From biochemistry to physiology and back again. Biochemistry 50: 7842-7857, 2011.

16. Sato $\mathrm{S}$ and Hughes RC: Binding specificity of a baby hamster kidney lectin for $\mathrm{H}$ type I and II chains, polylactosamine glycans, and appropriately glycosylated forms of laminin and fibronectin. J Biol Chem 267: 6983-6990, 1992.

17. Yamaoka A, Kuwabara I, Frigeri LG and Liu FT: A human lectin, galectin-3 (epsilon bp/Mac-2), stimulates superoxide production by neutrophils. J Immunol 154: 3479-3487, 1995.

18. Kuwabara I and Liu FT: Galectin-3 promotes adhesion of human neutrophils to laminin. J Immunol 156: 3939-3944, 1996.

19. Karlsson A, Follin P, Leffler H and Dahlgren C: Galectin-3 activates the NADPH-oxidase in exudated but not peripheral blood neutrophils. Blood 91: 3430-3438, 1998.

20. ten Oever J, Giamarellos-Bourboulis EJ, van de Veerdonk FL, Stelma FF, Simon A, Janssen M, Johnson M, Pachot A, Kullberg BJ, Joosten LA and Netea MG: Circulating galectin-3 in infections and non-infectious inflammatory diseases. Eur $\mathbf{J}$ Clin Microbiol Infect Dis 32: 1605-1610, 2013.

21. Ruvolo PP: Galectin 3 as a guardian of the tumor microenvironment. Biochim Biophys Acta 1863: 427-437, 2016.

22. Salomonsson E, Carlsson MC, Osla V, Hendus-Altenburger R, Kahl-Knutson B, Oberg CT, Sundin A, Nilsson R, Nordberg-Karlsson E, Nilsson UJ, et al: Mutational tuning of galectin-3 specificity and biological function. J Biol Chem 285: 35079-35091, 2010.

23. Delacour D, Greb C, Koch A, Salomonsson E, Leffler H, Le Bivic A and Jacob R: Apical sorting by galectin-3-dependent glycoprotein clustering. Traffic 8: 379-388, 2007.

24. Anderson KG, Stromnes IM and Greenberg PD: Obstacles posed by the tumor microenvironment to $\mathrm{T}$ cell activity: A case for synergistic therapies. Cancer Cell 31: 311-325, 2017.

25. Gordon-Alonso M, Hirsch T, Wildmann C and van der Bruggen P: Galectin-3 captures interferon-gamma in the tumor matrix reducing chemokine gradient production and T-cell tumor infiltration. Nat Commun 8: 793, 2017.

26. de Oliveira JT, Ribeiro C, Barros R, Gomes C, de Matos AJ, Reis CA, Rutteman GR and Gärtner F: Hypoxia up-regulates galectin-3 in mammary tumor progression and metastasis. PLoS One 10: e0134458, 2015.

27. Sun W, Li L, Li LJ, Yang QQ, Zhang ZR and Huang Y: Two birds, one stone: Dual targeting of the cancer cell surface and subcellular mitochondria by the galectin-3-binding peptide G3-C12. Acta Pharmacol Sin 38: 806-822, 2017.

28. Bacchi PS, Bloise AC, Bustos SO, Zimmermann L, Chammas R and Rabbani SR: Metabolism under hypoxia in Tm1 murine melanoma cells is affected by the presence of galectin-3, a metabolomics approach. Springerplus 3: 470, 2014.

29. Pejnovic NN, Pantic JM, Jovanovic IP, Radosavljevic GD, Milovanovic MZ, Nikolic IG, Zdravkovic NS, Djukic AL, Arsenijevic NN and Lukic ML: Galectin-3 deficiency accelerates high-fat diet-induced obesity and amplifies inflammation in adipose tissue and pancreatic islets. Diabetes 62: 1932-1944, 2013.

30. Yu F, Finley RL Jr, Raz A and Kim HR: Galectin-3 translocates to the perinuclear membranes and inhibits cytochrome $\mathrm{c}$ release from the mitochondria. A role for synexin in galectin-3 translocation. J Biol Chem 277: 15819-15827, 2002.

31. Sciacchitano S, Lavra L, Morgante A, Ulivieri A, Magi F, De Francesco GP, Bellotti C, Salehi LB and Ricci A: Galectin-3: One molecule for an alphabet of diseases, from A to Z. Int J Mol Sci 19: 379, 2018.

32. Cardoso AC, Andrade LN, Bustos SO and Chammas R: Galectin-3 determines tumor cell adaptive strategies in stressed tumor microenvironments. Front Oncol 6: 127, 2016.

33. Lee YK, Lin TH, Chang CF and Lo YL: Galectin-3 silencing inhibits epirubicin-induced ATP binding cassette transporters and activates the mitochondrial apoptosis pathway via $\beta$-catenin/GSK-3 $\beta$ modulation in colorectal carcinoma. PLoS One 8: e82478, 2013.

34. Fei F, Joo EJ, Tarighat SS, Schiffer I, Paz H, Fabbri M, Abdel-Azim H, Groffen J and Heisterkamp N: B-cell precursor acute lymphoblastic leukemia and stromal cells communicate through galectin-3. Oncotarget 6: 11378-11394, 2015.
35. Yamamoto-Sugitani M, Kuroda J, Ashihara E, Nagoshi H, Kobayashi T, Matsumoto Y, Sasaki N, Shimura Y, Kiyota M, Nakayama R, et al: Galectin-3 (Gal-3) induced by leukemia microenvironment promotes drug resistance and bone marrow lodgment in chronic myelogenous leukemia. Proc Natl Acad Sci USA 108: 17468-17473, 2011.

36. Silverman AM, Nakata R, Shimada H, Sposto R and DeClerck YA: A galectin-3-dependent pathway upregulates interleukin-6 in the microenvironment of human neuroblastoma. Cancer Res 72: 2228-2238, 2012.

37. Nakayama R, Kuroda J, Taniyama N, Yamamoto-Sugitani M, Wada S, Kiyota M, Mizutani S, Chinen Y, Matsumoto Y, Nagoshi H, et al: Suppression of SERPINA1-albumin complex formation by galectin-3 overexpression leads to paracrine growth promotion of chronic myelogenous leukemia cells. Leuk Res 38: 103-108, 2014.

38. Ruvolo PP, Ruvolo VR, Burks JK, Qiu Y, Wang RY, Shpall EJ, Mirandola L, Hail N Jr, Zeng Z, McQueen T, et al: Role of MSC-derived galectin 3 in the AML microenvironment. Biochim Biophys Acta Mol Cell Res 1865: 959-969, 2018.

39. Song S, Mazurek N, Liu C, Sun Y, Ding QQ, Liu K, Hung MC and Bresalier RS: Galectin-3 mediates nuclear beta-catenin accumulation and Wnt signaling in human colon cancer cells by regulation of glycogen synthase kinase-3beta activity. Cancer Res 69: 1343-1349, 2009.

40. McCubrey JA, Davis NM, Abrams SL, Montalto G, Cervello M, Basecke J, Libra M, Nicoletti F, Cocco L, Martelli AM and Steelman LS: Diverse roles of GSK-3: Tumor promoter-tumor suppressor, target in cancer therapy. Adv Biol Regul 54: 176-196, 2014.

41. Hermida MA, Dinesh Kumar J and Leslie NR: GSK3 and its interactions with the PI3K/AKT/mTOR signalling network. Adv Biol Regul 65: 5-15, 2017.

42. Ricciardi MR, Mirabilii S, Licchetta R, Piedimonte M and Tafuri A: Targeting the Akt, GSK-3, Bcl-2 axis in acute myeloid leukemia. Adv Biol Regul 65: 36-58, 2017.

43. Ruvolo PP: GSK-3 as a novel prognostic indicator in leukemia. Adv Biol Regul 65: 26-35, 2017.

44. Krause S, Pfeiffer C, Strube S, Alsadeq A, Fedders H, Vokuhl C, Loges S, Waizenegger J, Ben-Batalla I, Cario G, et al: Mer tyrosine kinase promotes the survival of $t(1 ; 19)$-positive acute lymphoblastic leukemia (ALL) in the central nervous system (CNS). Blood 125: 820-830, 2015.

45. Zeng Y, Danielson KG, Albert TJ, Shapiro IM and Risbud MV: HIF-1 alpha is a regulator of galectin-3 expression in the intervertebral disc. J Bone Miner Res 22: 1851-1861, 2007.

46. Neder L, Marie SK, Carlotti CG Jr, Gabbai AA, Rosemberg S, Malheiros SM, Siqueira RP, Oba-Shinjo SM, Uno M, Aguiar PH, et al: Galectin-3 as an immunohistochemical tool to distinguish pilocytic astrocytomas from diffuse astrocytomas, and glioblastomas from anaplastic oligodendrogliomas. Brain Pathol 14: 399-405, 2004.

47. Rêgo MJ, Vieira de Mello GS, da Silva Santos CA, Chammas R and Beltrão EI: Implications on glycobiological aspects of tumor hypoxia in breast ductal carcinoma in situ. Med Mol Morphol 46: 92-96, 2013.

48. Ikemori RY, Machado CM, Furuzawa KM, Nonogaki S, Osinaga E, Umezawa K, de Carvalho MA, Verinaud L and Chammas R: Galectin-3 up-regulation in hypoxic and nutrient deprived microenvironments promotes cell survival. PLoS One 9: e111592, 2014.

49. Liu L, Sakai T, Sano N and Fukui K: Nucling mediates apoptosis by inhibiting expression of galectin- 3 through interference with nuclear factor kappaB signalling. Biochem J 380: 31-41, 2004.

50. Radosavljevic G, Jovanovic I, Majstorovic I, Mitrovic M, Lisnic VJ, Arsenijevic N, Jonjic S and Lukic ML: Deletion of galectin-3 in the host attenuates metastasis of murine melanoma by modulating tumor adhesion and NK cell activity. Clin Exp Metastasis 28: 451-462, 2011.

51. Kouo T, Huang L, Pucsek AB, Cao M, Solt S, Armstrong T and Jaffee E: Galectin-3 shapes antitumor immune responses by suppressing $\mathrm{CD}^{+} \mathrm{T}$ cells via LAG-3 and inhibiting expansion of plasmacytoid dendritic cells. Cancer Immunol Res 3: 412-423, 2015.

52. Demotte N, Wieërs G, Van Der Smissen P, Moser M, Schmidt C, Thielemans K, Squifflet JL, Weynand B, Carrasco J, Lurquin C, et al: A galectin-3 ligand corrects the impaired function of human CD4 and CD8 tumor-infiltrating lymphocytes and favors tumor rejection in mice. Cancer Res 70: 7476-7488, 2010. 
53. Gordon-Alonso M, Demotte $\mathrm{N}$ and van der Bruggen P: Sugars boost exhausted tumor-infiltrating lymphocytes by counteracting immunosuppressive activities of galectins. Oncoimmunology 3: e28783, 2014.

54. Peng W, Wang HY, Miyahara Y, Peng G and Wang RF: Tumor-associated galectin-3 modulates the function of tumor-reactive T cells. Cancer Res 68: 7228-7236, 2008.

55. Zubieta MR, Furman D, Barrio M, Bravo AI, Domenichini E and Mordoh J: Galectin-3 expression correlates with apoptosis of tumor-associated lymphocytes in human melanoma biopsies. Am J Pathol 168: 1666-1675, 2006.

56. Tsuboi S, Sutoh M, Hatakeyama S, Hiraoka N, Habuchi T, Horikawa Y, Hashimoto Y, Yoneyama T, Mori K, Koie T, et al A novel strategy for evasion of NK cell immunity by tumours expressing core2 O-glycans. EMBO J 30: 3173-3185, 2011.

57. Suzuki Y, Sutoh M, Hatakeyama S, Mori K, Yamamoto H, Koie T, Saitoh H, Yamaya K, Funyu T, Habuchi T, et al: MUC1 carrying core $2 O$-glycans functions as a molecular shield against NK cell attack, promoting bladder tumor metastasis. Int J Oncol 40 : $1831-1838,2012$

58. Wang W, Guo H, Geng J, Zheng X, Wei H, Sun R and Tian Z: Tumor-released galectin-3, a soluble inhibitory ligand of human NKp30, plays an important role in tumor escape from NK cell attack. J Biol Chem 289: 33311-33319, 2014.

59. Melief SM, Visser M, van der Burg SH and Verdegaal EME: IDO and galectin-3 hamper the ex vivo generation of clinical grade tumor-specific $\mathrm{T}$ cells for adoptive cell therapy in metastatic melanoma. Cancer Immunol Immunother 66: 913-926, 2017.

60. Colomb F, Wang W, Simpson D, Zafar M, Beynon R, Rhodes JM and Yu LG: Galectin-3 interacts with the cell-surface glycoprotein CD146 (MCAM, MUC18) and induces secretion of metastasis-promoting cytokines from vascular endothelial cells. J Biol Chem 292: 8381-8389, 2017.

61. Pop VV, Seicean A, Lupan I, Samasca G and Burz CC: IL-6 roles-molecular pathway and clinical implication in pancreatic cancer-A systemic review. Immunol Lett 181: 45-50, 2017.

62. Stillman BN, Hsu DK, Pang M, Brewer CF, Johnson P, Liu FT and Baum LG: Galectin-3 and galectin-1 bind distinct cell surface glycoprotein receptors to induce T cell death. J Immunol 176 : 778-789, 2006

63. Yang RY, Hsu DK and Liu FT: Expression of galectin-3 modulates T-cell growth and apoptosis. Proc Natl Acad Sci USA 93: 6737-6742, 1996.

64. Haudek KC, Spronk KJ, Voss PG, Patterson RJ, Wang JL and Arnoys EJ: Dynamics of galectin-3 in the nucleus and cytoplasm. Biochim Biophys Acta 1800: 181-189, 2010.

65. van den Brûle F, Califice S and Castronovo V: Expression of galectins in cancer: A critical review. Glycoconj J 19: 537-542, 2002.

66. Liu FT and Rabinovich GA: Galectins as modulators of tumour progression. Nat Rev Cancer 5: 29-41, 2005.

67. Nakahara S, Oka N and Raz A: On the role of galectin-3 in cancer apoptosis. Apoptosis 10: 267-275, 2005.

68. Honjo Y, Inohara H, Akahani S, Yoshii T, Takenaka Y, Yoshida J, Hattori K, Tomiyama Y, Raz A and Kubo T: Expression of cytoplasmic galectin-3 as a prognostic marker in tongue carcinoma. Clin Cancer Res 6: 4635-4640, 2000.

69. van den Brûle FA, Waltregny D, Liu FT and Castronovo V: Alteration of the cytoplasmic/nuclear expression pattern of galectin-3 correlates with prostate carcinoma progression. Int $\mathbf{J}$ Cancer 89: 361-367, 2000.

70. Brown ER, Doig T, Anderson N, Brenn T, Doherty V, Xu Y, Bartlett JM, Smyth JF and Melton DW: Association of galectin-3 expression with melanoma progression and prognosis. Eur J Cancer 48: 865-874, 2012.

71. Califice S, Castronovo V, Bracke M and van den Brûle F: Dual activities of galectin-3 in human prostate cancer: Tumor suppression of nuclear galectin-3 vs tumor promotion of cytoplasmic galectin-3. Oncogene 23: 7527-7536, 2004.

72. Dumic J, Dabelic S and Flögel M: Galectin-3: An open-ended story. Biochim Biophys Acta 1760: 616-635, 2006.

73. Levy R, Biran A, Poirier F, Raz A and Kloog Y: Galectin-3 mediates cross-talk between K-Ras and Let-7c tumor suppressor microRNA. PLoS One 6: e27490, 2011

74. Song S, Ji B, Ramachandran V, Wang H, Hafley M, Logsdon C and Bresalier RS: Overexpressed galectin-3 in pancreatic cancer induces cell proliferation and invasion by binding Ras and activating Ras signaling. PLoS One 7: e42699, 2012.
75. Streetly MJ, Maharaj L, Joel S, Schey SA, Gribben JG and Cotter FE: GCS-100, a novel galectin-3 antagonist, modulates MCL-1, NOXA, and cell cycle to induce myeloma cell death. Blood 115: 3939-3948, 2010.

76. Harazono Y, Nakajima K and Raz A: Why anti-Bcl-2 clinical trials fail: A solution. Cancer Metastasis Rev 33: 285-294, 2014.

77. Song L, Tang JW, Owusu L, Sun MZ, Wu J and Zhang J: Galectin-3 in cancer. Clin Chim Acta 431: 185-191, 2014.

78. Prieto VG, Mourad-Zeidan AA, Melnikova V, Johnson MM, Lopez A, Diwan AH, Lazar AJ, Shen SS, Zhang PS, Reed JA, et al: Galectin-3 expression is associated with tumor progression and pattern of sun exposure in melanoma. Clin Cancer Res 12: 6709-6715, 2006.

79. Nangia-Makker P, Honjo Y, Sarvis R, Akahani S, Hogan V, Pienta KJ and Raz A: Galectin-3 induces endothelial cell morphogenesis and angiogenesis. Am J Pathol 156: 899-909, 2000.

80. Henderson NC, Mackinnon AC, Farnworth SL, Poirier F, Russo FP, Iredale JP, Haslett C, Simpson KJ and Sethi T: Galectin-3 regulates myofibroblast activation and hepatic fibrosis. Proc Natl Acad Sci USA 103: 5060-5065, 2006.

81. Sioud M, Mobergslien A, Boudabous A and Fløisand Y: Evidence for the involvement of galectin-3 in mesenchymal stem cell suppression of allogeneic T-cell proliferation. Scand J Immunol 71: 267-274, 2010.

82. Henderson NC, Mackinnon AC, Farnworth SL, Kipari T, Haslett C, Iredale JP, Liu FT, Hughes J and Sethi T: Galectin-3 expression and secretion links macrophages to the promotion of renal fibrosis. Am J Pathol 172: 288-298, 2008.

83. O'Driscoll L, Linehan R, Liang YH, Joyce H, Oglesby I and Clynes M: Galectin-3 expression alters adhesion, motility and invasion in a lung cell line (DLKP), in vitro. Anticancer Res 22: 3117-3125, 2002.

84. Melo FH, Butera D, Junqueira Mde S, Hsu DK, da Silva AM, Liu FT, Santos MF and Chammas R: The promigratory activity of the matricellular protein galectin-3 depends on the activation of PI-3 kinase. PLoS One 6: e29313, 2011.

85. Kim SJ, Shin JY, Lee KD, Bae YK, Choi IJ, Park SH and Chun KH: Galectin-3 facilitates cell motility in gastric cancer by up-regulating protease-activated receptor-1 (PAR-1) and matrix metalloproteinase-1 (MMP-1). PLoS One 6: e25103, 2011.

86. Hughes RC: Galectins as modulators of cell adhesion. Biochimie 83: 667-676, 2001

87. Ochieng J, Leite-Browning ML and Warfield P: Regulation of cellular adhesion to extracellular matrix proteins by galectin-3. Biochem Biophys Res Commun 246: 788-791, 1998.

88. Ochieng J, Warfield P, Green-Jarvis B and Fentie I: Galectin-3 regulates the adhesive interaction between breast carcinoma cells and elastin. J Cell Biochem 75: 505-514, 1999.

89. Nangia-Makker P, Balan V and Raz A: Regulation of tumor progression by extracellular galectin-3. Cancer Microenviron 1: 43-51,2008.

90. Wu KL, Kuo CM, Huang EY, Pan HM, Huang CC, Chen YF, Hsiao CC and Yang KD: Extracellular galectin-3 facilitates colon cancer cell migration and is related to the epidermal growth factor receptor. Am J Transl Res 10: 2402, 2018.

91. Partridge EA, Le Roy C, Di Guglielmo GM, Pawling J, Cheung P, Granovsky M, Nabi IR, Wrana JL and Dennis JW: Regulation of cytokine receptors by Golgi N-glycan processing and endocytosis. Science 306: 120-124, 2004

92. Saeland E, Belo AI, Mongera S, van Die I, Meijer GA and van Kooyk Y: Differential glycosylation of MUC1 and CEACAM5 between normal mucosa and tumour tissue of colon cancer patients. Int J Cancer 131: 117-128, 2012.

93. Markowska AI, Liu FT and Panjwani N: Galectin-3 is an important mediator of VEGF- and bFGF-mediated angiogenic response. J Exp Med 207: 1981-1993, 2010.

94. Demotte N, Bigirimana R, Wieërs G, Stroobant V, Squifflet JL, Carrasco J, Thielemans K, Baurain JF, Van Der Smissen P, Courtoy PJ and van der Bruggen P: A short treatment with galactomannan GM-CT-01 corrects the functions of freshly isolated human tumor-infiltrating lymphocytes. Clin Cancer Res 20: 1823-1833, 2014.

95. Dong R, Zhang M, Hu Q, Zheng S, Soh A, Zheng Y and Yuan H: Galectin-3 as a novel biomarker for disease diagnosis and a target for therapy (Review). Int J Mol Med 41: 599-614, 2018.

96. Traber PG and Zomer E: Therapy of experimental NASH and fibrosis with galectin inhibitors. PLoS One 8: e83481, 2013. 
97. Bayes-Genis A, de Antonio M, Vila J, Peñafiel J, Galán A. Barallat J, Zamora E, Urrutia A and Lupón J: Head-to-head comparison of 2 myocardial fibrosis biomarkers for long-term heart failure risk stratification: ST2 versus galectin-3. J Am Coll Cardiol 63: 158-166, 2014.

98. Linch S, Kasiewicz MJ, McNamara M, Hilgart I, Farhad M and Redmond W: Galectin-3 inhibition using novel inhibitor GR-MD-02 improves survival and immune function while reducing tumor vasculature. J Immunother Cancer 3 (Suppl 2): P306, 2015.

99. Courtnay R, Ngo DC, Malik N, Ververis K, Tortorella SM and Karagiannis TC: Cancer metabolism and the Warburg effect: The role of HIF-1 and PI3K. Mol Biol Rep 42: 841-851, 2015.

100. Vander Heiden MG, Cantley LC and Thompson CB: Understanding the Warburg effect: The metabolic requirements of cell proliferation. Science 324: 1029-1033, 2009.

101. Cairns RA, Harris IS and Mak TW: Regulation of cancer cell metabolism. Nat Rev Cancer 11: 85-95, 2011.

102. Zheng J, Lu W, Wang C, Xing Y, Chen X and Ai Z: Galectin-3 induced by hypoxia promotes cell migration in thyroid cancer cells. Oncotarget 8: 101475-101488, 2017.

103. Rinaldi G, Rossi M and Fendt SM: Metabolic interactions in cancer: Cellular metabolism at the interface between the microenvironment, the cancer cell phenotype and the epigenetic landscape. Wiley Interdiscip Rev Syst Biol Med 10, 2018.

104. Gao X, Balan V, Tai G and Raz A: Galectin-3 induces cell migration via a calcium-sensitive MAPK/ERK1/2 pathway. Oncotarget 5: 2077-2084, 2014.

105. Pavlova NN and Thompson CB: The emerging hallmarks of cancer metabolism. Cell Metab 23: 27-47, 2016.

106. Nakahara S and Raz A: Regulation of cancer-related gene expression by galectin-3 and the molecular mechanism of its nuclear import pathway. Cancer Metastasis Rev 26: 605-610, 2007

107. Yu F, Finley RL Jr, Raz A and Kim HR: Galectin-3 translocates to the perinuclear membranes and inhibits cytochrome $\mathrm{c}$ release from the mitochondria. A role for synexin in galectin-3 translocation. J Biol Chem 277: 15819-15827, 2002.

108. Wang D, You D and Li L: Galectin-3 regulates chemotherapy sensitivity in epithelial ovarian carcinoma via regulating mitochondrial function. J Toxicol Sci 44: 47-56, 2019.

109. Dupont J, Reverchon M, Cloix L, Froment P and Ramé C: Involvement of adipokines, AMPK, PI3K and the PPAR signaling pathways in ovarian follicle development and cancer. Int J Dev Biol 56: 959-967, 2012.

110. Wu Y, Sarkissyan M, Mcghee E, Lee S and Vadgama JV: Combined inhibition of glycolysis and AMPK induces synergistic breast cancer cell killing. Breast Cancer Res Treat 151: 529-539, 2015

111. Dos Santos SN, Sheldon H, Pereira JX, Paluch C, Bridges EM, El-Cheikh MC, Harris AL and Bernardes ES: Galectin-3 acts as an angiogenic switch to induce tumor angiogenesis via Jagged-1/Notch activation. Oncotarget 8: 49484-49501, 2017.

112. Dange MC, Agarwal AK and Kalraiya RD: Extracellular galectin-3 induces MMP9 expression by activating p38 MAPK pathway via lysosome-associated membrane protein-1 (LAMP1). Mol Cell Biochem 404: 79-86, 2015.

113. Simons AL, Orcutt KP, Madsen JM, Scarbrough PM and Spitz DR: The role of Akt pathway signaling in glucose metabolism and metabolic oxidative stress. In: Oxidative stress in cancer biology and therapy. Oxidative Stress in Applied Basic Research and Clinical Practice. Spitz D, Dornfeld K, Krishnan K and Gius D (eds). Humana Press, Totowa, NJ, pp21-46, 2012. http:// doi-org-443.webvpn.fjmu.edu.cn/10.1007/978-1-61779-397-4 2

114. Lu H, Forbes RA and Verma A: Hypoxia-inducible factor 1 activation by aerobic glycolysis implicates the Warburg effect in carcinogenesis. J Biol Chem 277: 23111-23115, 2002.

115. Manalo DJ, Rowan A, Lavoie T, Natarajan L, Kelly BD, Ye SQ, Garcia JG and Semenza GL: Transcriptional regulation of vascular endothelial cell responses to hypoxia by HIF-1. Blood 105: 659-669, 2005

116. Minet E, Michel G, Remacle J and Michiels C: Role of HIF-1 as a transcription factor involved in embryonic development, cancer progression and apoptosis (Review). Int J Mol Med 5: 253-262, 2000.

117. Kim JW, Tchernyshyov I, Semenza GL and Dang CV: HIF-1-mediated expression of pyruvate dehydrogenase kinase: A metabolic switch required for cellular adaptation to hypoxia. Cell Metab 3: 177-185, 2006.
118. Kariya Y, Oyama M, Hashimoto Y, Gu J and Kariya Y: $\beta 4$-Integrin/PI3K signaling promotes tumor progression through the galectin-3-N-glycan complex. Mol Cancer Res 16: 1024-1034, 2018

119. Lippert E, Falk W, Bataille F, Kähne T, Naumann M, Goeke M, Herfarth H, Schoelmerich J and Rogler G: Soluble galectin-3 is a strong, colonic epithelial-cell-derived, lamina propria fibroblast-stimulating factor. Gut 56: 43-51, 2007.

120. Wang S, Wu X, Zhang J, Chen Y, Xu J, Xia X, He S, Qiang F, $\mathrm{Li} \mathrm{A}$, Shu Y, et al: CHIP functions as a novel suppressor of tumour angiogenesis with prognostic significance in human gastric cancer. Gut 62: 496-508, 2013

121. Wilde L, Roche M, Domingo-Vidal M, Tanson K, Philp N, Curry $\mathbf{J}$ and Martinez-Outschoorn U: Metabolic coupling and the reverse Warburg effect in cancer: Implications for novel biomarker and anticancer agent development. Semin Oncol 44: 198-203, 2017.

122. Greijer AE, van der Groep P, Kemming D, Shvarts A, Semenza GL, Meijer GA, van de Wiel MA, Belien JA, van Diest PJ and van der Wall E: Up-regulation of gene expression by hypoxia is mediated predominantly by hypoxia-inducible factor 1 (HIF-1). J Pathol 206: 291-304, 2005.

123. Zhao W, Ajani JA, Sushovan G, Ochi N, Hwang R, Hafley M, Johnson RL, Bresalier RS, Logsdon CD, Zhang Z and Song S: Galectin-3 mediates tumor cell-stroma interactions by activating pancreatic stellate cells to produce cytokines via integrin signaling. Gastroenterology 154: 1524-1537.e6, 2018.

124. McCubrey JA, Rakus D, Gizak A, Steelman LS, Abrams SL, Lertpiriyapong K, Fitzgerald TL, Yang LV, Montalto G, Cervello $\mathrm{M}$, et al: Effects of mutations in Wnt/ $\beta$-catenin, hedgehog, Notch and PI3K pathways on GSK-3 activity-diverse effects on cell growth, metabolism and cancer. Biochim Biophys Acta 1863: 2942-2976, 2016.

125. Shimura T, Takenaka Y, Tsutsumi S, Hogan V, Kikuchi A and Raz A: Galectin-3, a novel binding partner of beta-catenin. Cancer Res 64: 6363-6367, 2004.

126. Liu C, Li Y, Semenov M, Han C, Baeg GH, Tan Y, Zhang Z, Lin $\mathrm{X}$ and $\mathrm{He} \mathrm{X}$ : Control of beta-catenin phosphorylation/degradation by a dual-kinase mechanism. Cell 108: 837-847, 2002

127. Sun S, Schiller JH, Spinola M and Minna JD: New molecularly targeted therapies for lung cancer. J Clin Invest 117: 2740-2750, 2007.

128. Yoshimura A, Gemma A, Hosoya Y, Komaki E, Hosomi Y, Okano T, Takenaka K, Matuda K, Seike M, Uematsu K, et al: Increased expression of the LGALS3 (galectin 3) gene in human non-small-cell lung cancer. Genes Chromosomes Cancer 37: $159-164,2003$

129. Nakayama S, Soejima K, Yasuda H, Yoda S, Satomi R, Ikemura S, Terai H, Sato T, Yamaguchi N, Hamamoto J, et al: FOXD1 expression is associated with poor prognosis in non-small cell lung cancer. Anticancer Res 35: 261-268, 2015.

130. Li CH, Chang YC, Hsiao M and Liang SM: FOXD1 and Gal-3 form a positive regulatory loop to regulate lung cancer aggressiveness. Cancers (Basel) 11: 1897, 2019

131. Kataoka Y, Igarashi T, Ohshio Y, Fujita T and Hanaoka J: Predictive importance of galectin-3 for recurrence of non-small cell lung cancer. Gen Thorac Cardiovasc Surg 67: 704-711, 2019.

132. Chung LY, Tang SJ, Wu YC, Sun GH, Liu HY and Sun KH: Galectin-3 augments tumor initiating property and tumorigenicity of lung cancer through interaction with $\beta$-catenin. Oncotarget 6: 4936-4952, 2015.

133. Rabinovich GA and Toscano MA: Turning 'sweet' on immunity: Galectin-glycan interactions in immune tolerance and inflammation. Nat Rev Immunol 9: 338-352, 2009.

134. Toscano MA, Bianco GA, Ilarregui JM, Croci DO, Correale J Hernandez JD, Zwirner NW, Poirier F, Riley EM, Baum LG and Rabinovich GA: Differential glycosylation of TH1, TH2 and TH-17 effector cells selectively regulates susceptibility to cell death. Nat Immunol 8: 825-834, 2007.

135. Demetriou M, Granovsky M, Quaggin S and Dennis JW: Negative regulation of T-cell activation and autoimmunity by Mgat5 N-glycosylation. Nature 409: 733-739, 2001.

136. Novak R, Dabelic S and Dumic J: Galectin-1 and galectin-3 expression profiles in classically and alternatively activated human macrophages. Biochim Biophys Acta 1820: 1383-1390, 2012.

137. Capalbo C, Scafetta G, Filetti M, Marchetti P and Bartolazzi A: Predictive biomarkers for checkpoint inhibitor-based immunotherapy: The Galectin-3 signature in NSCLCs. Int J Mol Sci 20: $1607,2019$. 
138. Gibney GT, Weiner LM and Atkins MB: Predictive biomarkers for checkpoint inhibitor-based immunotherapy. Lancet Oncol 17: e542-e551,2016.

139. Tang W, Huang $\mathrm{C}$, Tang $\mathrm{C}, \mathrm{Xu} \mathrm{J}$ and Wang H: Galectin-3 may serve as a potential marker for diagnosis and prognosis in papillary thyroid carcinoma: A meta-analysis. Onco Targets Ther 9: 455-460, 2016.

140. Xue G, Liu J, Huang J, Zhang J, Zhang W, Wu J and Shang X: Detection of galectin-3 in both serum and tissue for early diagnosis of thyroid carcinoma. Nan Fang Yi Ke Da Xue Xue Bao 33: 1027-1030, 2013 (In Chinese).

141. Yılmaz E, Karşıdağ T, Tatar C and Tüzün S: Serum galectin-3: Diagnostic value for papillary thyroid carcinoma. Ulus Cerrahi Derg 31: 192-196, 2015.

142. Shi RL, Qu N, Liao T, Wang YL, Wang Y, Sun GH and Ji QH: Expression, clinical significance and mechanism of Slit2 in papillary thyroid cancer. Int J Oncol 48: 2055-2062, 2016.

143. Shi RL, Qu N, Liao T, Wei WJ, Lu ZW, Ma B, Wang YL and Ji QH: Relationship of body mass index with BRAF (V600E) mutation in papillary thyroid cancer. Tumour Biol 37: 8383-8390, 2016.

144. Park YJ, Kim YA, Lee YJ, Kim SH, Park SY, Kim KW, Chung JK, Youn YK, Kim KH, Park DJ and Cho BY: Papillary microcarcinoma in comparison with larger papillary thyroid carcinoma in BRAF(V600E) mutation, clinicopathological features, and immunohistochemical findings. Head Neck 32: 38-45, 2010

145. Batistatou A, Charalabopoulos K, Nakanishi Y, Vagianos C, Hirohashi S, Agnantis NJ and Scopa CD: Differential expression of dysadherin in papillary thyroid carcinoma and microcarcinoma: Correlation with E-cadherin. Endocr Pathol 19: 197-202, 2008.

146. Huang L, Wang X, Huang X, Gui H, Li Y, Chen Q, Liu D and Liu L: Diagnostic significance of CK19, galectin-3, CD56, TPO and Ki67 expression and BRAF mutation in papillary thyroid carcinoma. Oncol Lett 15: 4269-4277, 2018.

147. Lu ZZ, Zhang Y, Wei SF, Li DS, Zhu QH, Sun SJ, Li M and Li LI: Outcome of papillary thyroid microcarcinoma: Study of 1,990 cases. Mol Clin Oncol 3: 672-676, 2015.

148. Nasr MR, Mukhopadhyay S, Zhang S and Katzenstein AL: Absence of the BRAF mutation in HBME1+ and CK19+ atypical cell clusters in Hashimoto thyroiditis: Supportive evidence against preneoplastic change. Am J Clin Pathol 132: 906-912, 2009

149. Paz A, Haklai R, Elad-Sfadia G, Ballan E and Kloog Y: Galectin-1 binds oncogenic H-Ras to mediate Ras membrane anchorage and cell transformation. Oncogene 20: 7486-7493, 2001
150. Trent JC II, McConkey DJ, Loughlin SM, Harbison MT, Fernandez A and Ananthaswamy HN: Ras signaling in tumor necrosis factor-induced apoptosis. EMBO J 15: 4497-4505, 1996.

151. Crul M, de Klerk GJ, Beijnen JH and Schellens JH: Ras biochemistry and farnesyl transferase inhibitors: A literature survey. Anticancer Drugs 12: 163-184, 2001.

152. Adjei AA: Blocking oncogenic Ras signaling for cancer therapy. J Natl Cancer Inst 93: 1062-1074, 2001.

153. Levy R, Grafi-Cohen M, Kraiem Z and Kloog Y: Galectin-3 promotes chronic activation of K-Ras and differentiation block in malignant thyroid carcinomas. Mol Cancer Ther 9: 2208-2219, 2010.

154. Nangia-Makker P, Conklin J, Hogan V and Raz A: Carbohydrate-binding proteins in cancer, and their ligands as therapeutic agents. Trends Mol Med 8: 187-192, 2002.

155. Menachem A, Bodner O, Pastor J, Raz A and Kloog Y: Inhibition of malignant thyroid carcinoma cell proliferation by Ras and galectin-3 inhibitors. Cell Death Discov 1: 15047, 2015

156. Rosenberg SA, Yannelli JR, Yang JC, Topalian SL, Schwartzentruber DJ, Weber JS, Parkinson DR, Seipp CA, Einhorn JH and White DE: Treatment of patients with metastatic melanoma with autologous tumor-infiltrating lymphocytes and interleukin 2. J Natl Cancer Inst 86: 1159-1166, 1994.

157. Li ZW, Wang Y, Xue WC, Si L, Cui CL, Cao DF, Zhou LX, Guo J and Lu AP: Expression and prognostic significance of galectin-1 and galectin-3 in benign nevi and melanomas. Zhonghua Bing Li Xue Za Zhi 42: 801-805, 2013 (In Chinese).

158. Ma XH, Piao SF, Dey S, Mcafee Q, Karakousis G, Villanueva J, Hart LS, Levi S, Hu J,Zhang G, et al: Targeting ER stress-induced autophagy overcomes BRAF inhibitor resistance in melanoma. J Clin Invest 124: 1406-1417, 2014.

159. Villanueva J, Vultur A, Lee JT, Somasundaram R, Fukunaga-Kalabis M, Cipolla AK, Wubbenhorst B, Xu X, Gimotty PA, Kee D, et al: Acquired resistance to BRAF inhibitors mediated by a RAF kinase switch in melanoma can be overcome by cotargeting MEK and IGF-1R/PI3K. Cancer Cell 18: 683-695, 2010.

160. Mourad-Zeidan AA, Melnikova VO, Wang H, Raz A and Bar-Eli M: Expression profiling of Galectin-3-depleted melanoma cells reveals its major role in melanoma cell plasticity and vasculogenic mimicry. Am J Pathol 173: 1839-1852, 2008. 